\title{
Surface Water Quality Assessment of Wular Lake, A Ramsar Site in Kashmir Himalaya, Using Discriminant Analysis and WQI
}

\author{
Salim Aijaz Bhat and Ashok K. Pandit \\ Aquatic Ecology Laboratory, Centre of Research for Development (CORD), University of Kashmir, Jammu and Kashmir 190006, India \\ Correspondence should be addressed to Salim Aijaz Bhat; salimaijaz@gmail.com
}

Received 27 June 2014; Accepted 16 July 2014; Published 31 August 2014

Academic Editor: Winn-Jung Huang

Copyright (c) 2014 S. A. Bhat and A. K. Pandit. This is an open access article distributed under the Creative Commons Attribution License, which permits unrestricted use, distribution, and reproduction in any medium, provided the original work is properly cited.

\begin{abstract}
Multivariate techniques, discriminant analysis, and WQI were applied to analyze a water quality data set including 27 parameters at 5 sites of the Lake Wular in Kashmir Himalaya from 2011 to 2013 to investigate spatiotemporal variations and identify potential pollution sources. Spatial and temporal variations in water quality parameters were evaluated through stepwise discriminant analysis (DA). The first spatial discriminant function (DF) accounted for $76.5 \%$ of the total spatial variance, and the second DF accounted for $19.1 \%$. The mean values of water temperature, EC, total- $\mathrm{N}, \mathrm{K}$, and silicate showed a strong contribution to discriminate the five sampling sites. The mean concentration of $\mathrm{NO}_{2}-\mathrm{N}$, total-N, and sulphate showed a strong contribution to discriminate the four sampling seasons and accounted for most of the expected seasonal variations. The order of major cations and anions was $\mathrm{Ca}^{2+}>\mathrm{Mg}^{2+}>\mathrm{Na}^{+}>\mathrm{K}^{+}$and $\mathrm{Cl}^{-}>\mathrm{SO}^{2-}>\mathrm{SiO}_{2}{ }^{2-}$ respectively. The results of water quality index, employing thirteen core parameters vital for drinking water purposes, showed values of 49.2, 46.5, 47.3, 40.6, and 37.1 for sites I, II, III, IV, and V, respectively. These index values reflect that the water of lake is in good condition for different purposes but increased values alarm us about future repercussions.
\end{abstract}

\section{Introduction}

Today surface water is most vulnerable to pollution due to its easy accessibility for disposal of pollutants and wastewaters. Worldwide surface water quality is governed by complex anthropogenic activities and natural processes $[1,2]$, including weathering, erosion, hydrological features, climate change, precipitation, industrial activities, agricultural land use, sewage discharge, and the human exploitation of water resources [1-6]. During the last decade, widespread deterioration in water quality of inland aquatic systems has been reported due to rapid development of industries, agriculture, and urban sprawl [7-9]. The evaluation of water quality in most countries has become a critical issue in recent years, especially due to concerns that freshwater will be a scarce resource in the future [10-13]. The protection of integrity of world water resources have been given topmost priority in the 21st century due to limited supply of fresh water and the role of anthropogenic activities in deteriorating the water quality[14-17]. This however cannot be achieved without a spatiotemporal evaluation of water quality of the aquatic systems of concern [18]. Numerous studies have also identified the pollution sources and potential influences of natural processes and anthropogenic activities on spatiotemporal variations in water quality $[19,20]$.

In view of the spatial and temporal variations in the hydrochemistry of surface waters, regular monitoring programs are required for reliable estimates of the water quality [12]. Water quality monitoring is a helpful tool not only to evaluate the impacts of pollution sources but also to ensure an efficient management of water resources and the protection of aquatic life [21]. However, the large and complicated data sets of water quality parameters generated by monitoring programs are often difficult to interpret latent meaningful information $[11,12,22,23]$ and require data reduction methods to simplify the data structure so as to extract useful and interpretable information [24]. Sequel to this challenge, the application of multivariate statistical and mathematical techniques such as discriminant analysis (DA) and WQI facilitates the interpretation of complex data matrices to 
TABLE 1: Sampling station locations and their coordinates.

\begin{tabular}{lcccccc}
\hline Study sites & & Latitude & Longitude & Elevation & Location & Water depth (m) \\
\hline Makhdomyari & Site I & $34^{\circ}-17^{\prime}-44.2^{\prime \prime}$ & $74^{\circ}-37^{\prime}-24.2^{\prime \prime}$ & 1597 & Southeastern & $1-3$ \\
Vintage & Site II & $34^{\circ}-24^{\prime}-08.1^{\prime \prime}$ & $74^{\circ}-32^{\prime}-39.1^{\prime \prime}$ & 1583 & Eastern side & $1-4$ \\
Ashtang & Site III & $34^{\circ}-24^{\prime}-3.8^{\prime \prime}$ & $74^{\circ}-32^{\prime}-41.7^{\prime \prime}$ & 1583 & Northwestern side & $0.5-4.5$ \\
Watlab & Site IV & $34^{\circ}-21^{\prime}-29.4^{\prime \prime}$ & $74^{\circ}-01^{\prime}-59.2^{\prime \prime}$ & 1577 & Western side & $1-5.5$ \\
Ningle & Site V & $34^{\circ}-17^{\prime}-16.6^{\prime \prime}$ & $74^{\circ}-30^{\prime}-26.6^{\prime \prime}$ & 1574 & Northern & $0.5-4.4$ \\
\hline
\end{tabular}

better understand the water quality and ecological status of studied systems [10, 12, 23, 25-28]. These statistical methods also help with the identification of possible factors/sources that influence water systems and offer a valuable tool for the reliable management of water resources as well as rapid solutions to pollution problems $[10,11,23,25,29,30]$.

In this study, physicochemical parameters of surface water quality directly affected by different pollution sources were monitored over two-year period. The data sets obtained were subjected to multivariate statistical technique, namely, discriminant analysis (DA), to obtain information about the similarities or dissimilarities among the monitoring periods and sites and to identify water quality variables responsible for spatial and temporal water quality variations in surface water. Besides multivariate statistical analysis, water quality index (a multifactor mathematical tool) was used to interpret water quality of studied lake numerically. It is regarded as one of the most effective ways to communicate water quality $[26,27,31]$ and is assessed on the basis of calculated water quality indices $[27,32]$. The index is a numeric expression used to transform large number of variables data into a single number, which represents the water quality level [33-35].

During the last decades, widespread deterioration in water quality of Wular lake has been reported due to anthropogenic influences (agricultural practices, increased exploitation of water resource, sewage runoff, agriculture, and urban sprawl) and natural processes (changes in precipitation, erosion, and weathering of crustal materials) $[36,37]$. Pollutants from anthropogenic activities have been increasingly produced and discharged into the Wular Lake, resulting in severe degradation of water quality, restricting the sustainable development of the local economies. Furthermore, enhanced input of nutrients from both natural as well as anthropogenic activities has resulted in the eutrophication of Wular Lake $[38,39]$. In the view of the above-mentioned pollution problems of Lake Wular, the present study was carried out with the objectives of finding pollution sources and causes of spatiotemporal variations in water quality.

\section{Materials and Methodology}

\subsection{Materials}

2.1.1. Study Area. The valley of Kashmir lies on the northern fringe of the Indian subcontinent and is lacustrine basin of the intermontane depression formed between the lesser and the greater Himalaya. It abounds a vast array of freshwater bodies, streams, lakes, ponds, and rivers famous for its beauty and natural scenery throughout the world. These numerous but varied freshwater ecosystems are of great aesthetic, cultural, socioeconomic, and geological value besides playing an important role in the conservation of genetic resources of both plants and animals. However, anthropogenic activities have resulted in heavy inflow of nutrients into these lakes from the catchment areas [40, 41]. These anthropogenic influences not only deteriorate the water quality but also affect the aquatic life in the lakes, as a result of which the process of aging of these lakes is hastened [42-44]. As a consequence, most of the lakes in the Kashmir valley are exhibiting eutrophication [45-48].

Geographically the Wular Lake, one of the largest wetlands of Asia, is situated at an altitude of $1,580 \mathrm{~m}$ (a.m.s.l), between $34^{\circ} 16^{\prime}-34^{\circ} 20^{\prime} \mathrm{N}$ latitudes and $74^{\circ} 33^{\prime}-74^{\circ} 44^{\prime} \mathrm{E}$ longitudes (Figure 1). Wular Lake, an ox-bow type lake, is of fluviatile origin located in the north-west of Kashmir about $35 \mathrm{~km}$ from Srinagar city, being formed by the meandering of River Jhelum, which is the main feeding channel besides other tributaries. It plays a significant role in the hydrography of the Kashmir valley not only by acting as a huge absorption basin for floodwaters but also for maintaining flows to support agriculture and hydropower generation as well as sports activities. The lake along with the extensive marshes surrounding is an important habitat for fish, accounting for $60 \%$ of the fish production within the state of Jammu and Kashmir [36]. The lake is largely shallow, with a maximum depth of $5.8 \mathrm{~m}$, the deeper part being on the western side opposite the hills of Baba Shakur Din. The lake is drained in the northeast by the only single outlet in the form of River Jhelum. General features of study stations are shown in Table 1. The catchment of the lake is comprised of slopping hills of the Zanskar ranges of the western Himalaya on the northeastern and northwestern sides which drain their runoff through various nallahs, where Erin and Madhumati are prominent. On the eastern and southern sides are the lowlying areas of Sonawari which used to get inundated almost every year until numerous criss-crossing embankments were constructed along River Jhelum. The lake area thus reclaimed has in the recent past been brought under cultivation of paddy and plantations of willow, poplar, and fruit trees. On the western side in the Sopore-Watlab section, low-lying areas have also been brought under paddy cultivation. In 1986, the lake was designated as wetland of national importance under the Indian Governments Wetlands Programme, and, in 1990, it was enlisted as a wetland of international importance under the Ramsar Convention of 1975 . However, a comprehensive study regarding the assessment of spatiotemporal hydrochemistry of the lake is lacking up to date. Morphometric features of Wular Lake are presented in Table 2. 


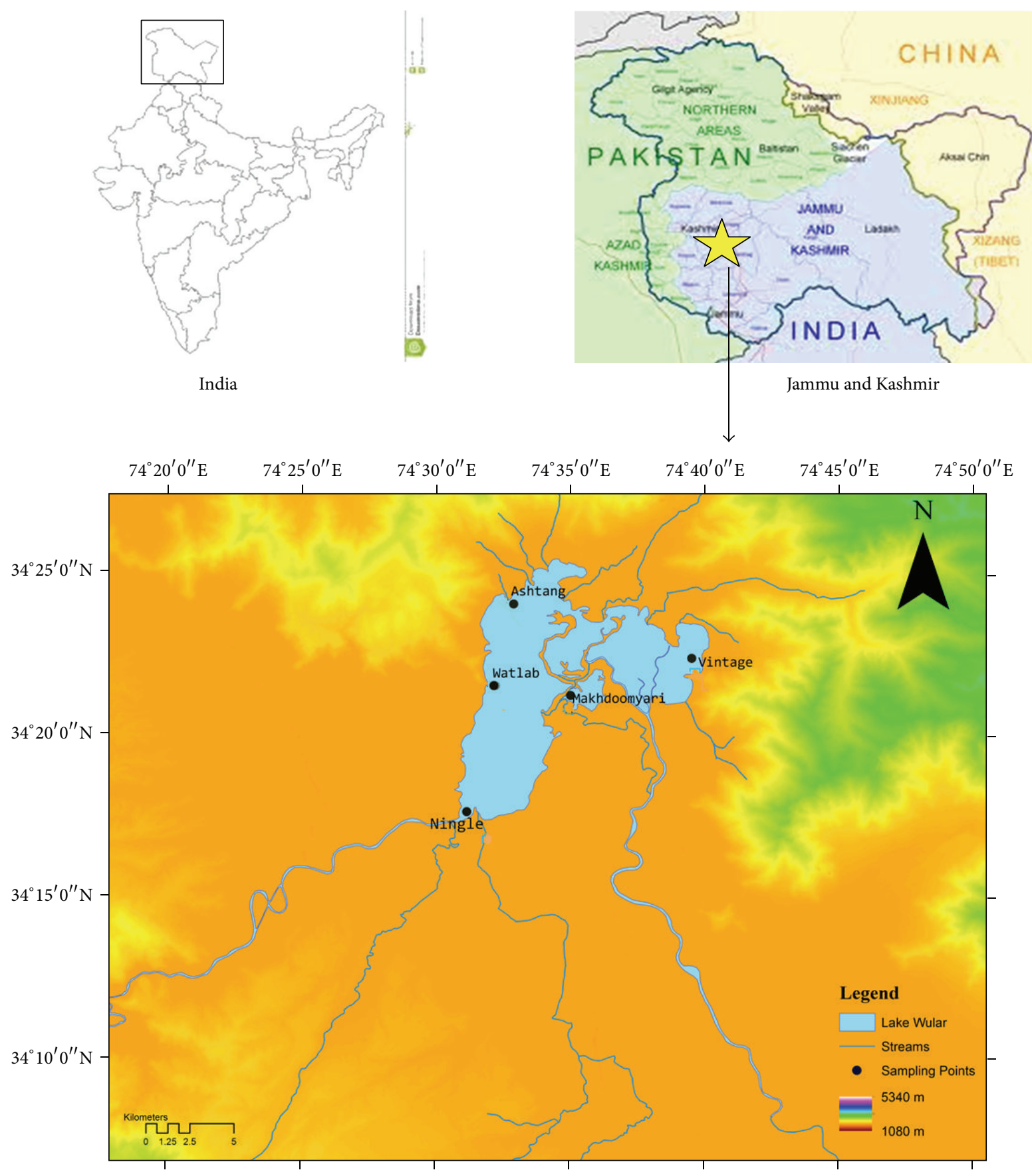

FIGURE 1: Showing layout of study area and surface water quality monitoring stations in Lake Wular.

\subsection{Methodology}

2.2.1. Sampling and Analysis . Surface water samples (0.5$1.0 \mathrm{~m}$ ) were collected from five sites on monthly basis from February 2011 to January 2013. On each sampling date, three replicates were collected at each sampling site. The water samples were preserved in prerinsed 1-L polypropylene, acidwashed sampling bottles at $4^{\circ} \mathrm{C}$ in darkness and analyzed within $24 \mathrm{~h}$. A saturated mercuric chloride solution was used at a final concentration of $0.2 \mathrm{mlL}^{-1}$ to stop all microbiological activities in the water samples. The parameters including depth, transparency, temperature, $\mathrm{pH}$, and conductivity were determined on spot while the rest of the parameters were determined in the laboratory. The parameters including orthophosphorus, total phosphorus, ammoniacal nitrogen, nitrite nitrogen, nitrate nitrogen, organic nitrogen (Kjeldahl nitrogen minus ammoniacal nitrogen), alkalinity, free $\mathrm{CO}_{2}$, conductivity, chloride, total hardness, calcium hardness, magnesium hardness, $\mathrm{Na}, \mathrm{K}$, silicate, sulphate, iron, and TDS were determined in the laboratory within 24 hours of sampling. The analysis was done by adopting standard methods of Mackereth, Golterman and Clymo, and APHA [49-51]. 
TABLE 2: Morphometric features of Lake Wular.

\begin{tabular}{lc}
\hline Max area & $61.6 \mathrm{Km}^{2}$ \\
Min area & $12.24 \mathrm{Km}^{2}$ \\
Average area & $31.415 \mathrm{Km}^{2}$ \\
Max volume & $371.825 \times 10^{6} \mathrm{~m}^{3}$ \\
Min volume & $187.735 \times 10^{6} \mathrm{~m}^{3}$ \\
Average volume & $267.675 \times 10^{6} \mathrm{~m}^{3}$ \\
Elevation & $1,580 \mathrm{~m}(\mathrm{amsl})$ \\
Maximum length & $16 \mathrm{~km}$ \\
Minimum breadth & $7.6 \mathrm{~km}$ \\
Shape & Elliptical \\
Max depth & $5.8 \mathrm{~m}$ \\
Minimum depth & $0.9 \mathrm{~m}$ \\
\hline
\end{tabular}

2.2.2. Statistical Analysis. Data for physicochemical parameters of water samples were presented as mean values and analyzed using descriptive analysis. We used standard deviation for describing the spatiotemporal degree of variations of the observed water quality parameters in Lake Wular, in different months and seasons. Prior to investigating the seasonal effect on water quality parameters, we divided the whole observation period into four fixed seasons: spring (March, April, and May), summer (June, July, and August), autumn (September, October, and November), and winter (December, January, and February).

2.2.3. Discriminant Analysis. Stepwise discriminant analysis (DA) which is also a multivariate statistical technique was used for spatiotemporal analysis of water quality data. Discriminant analysis (DA) is used to classify cases into categorical-dependent values, usually a dichotomy. If discriminant analysis is effective for a set of data, the classification table of correct and incorrect estimates will yield a high correct percentage. In DA, multiple quantitative attributes are used to discriminate between two or more naturally occurring groups. In contrast to CA, DA provides statistical classification of samples and is performed with prior knowledge of membership of objects to a particular group or cluster. Furthermore, DA helps in grouping samples sharing common properties. The DA technique builds up a discriminant function for each group, which operates on raw data $[10,12,52]$, as in the equation below:

$$
f\left(G_{i}\right)=k_{i}+\sum_{j=1}^{n} w_{i j} p_{i j},
$$

where $i$ is the number of groups $(G), k_{i}$ is the constant inherent to each group, $n$ is the number of parameters used to classify a set of data into a given group, and $w_{j}$ is the weight coefficient, assigned by DA to a given selected parameters $\left(p_{j}\right)$.

The weight coefficient maximizes the distance between the means of the criterion (dependent) variable. DA was performed, on each raw data matrix using stepwise modes in constructing discriminant functions, to evaluate both the spatial and temporal variations in water quality of the lake. The sites (spatial) and the seasons (temporal) were the grouping (dependent) variables, whereas all the measured parameters constituted the independent variables. Linear discriminant functions were used to describe or elucidate the differences between the sampling sites and the influence of season on water quality of each sampling site. The relative contribution of all variables to the separation of groups was highlighted [53].

2.2.4. Water Quality Index. Accurate and timely information on the quality of water is necessary to shape a sound public policy and to implement the water quality improvement programmes efficiently. One of the most effective ways to communicate information on water quality trends is with indices. The WQI is a mathematical instrument used to transform large quantities of water quality data into a single number which summarize different quality parameters. The WQI is an index of water quality for a particular use. Mathematically, the index is an arithmetic weighting of normalized water quality measurements. The weightings are different for different water usages [54]. The indices are broadly characterized into two parts: the physicochemical indices and the biological indices. The physicochemical indices are based on the values of various physicochemical parameters in a water sample, while biological indices are derived from the biological information and are calculated using the species composition of the sample, the diversity of species, their distribution pattern, the presence or absence of the indicator species or groups, and so forth [55]. Here, attempt has been made to calculate the water quality index of Wular Lake on the basis of Harkins [56] and Lohani [57] and subsequently modified by Tiwari et al. [58] based on two-year physicochemical data.

Quality Rating and Weightage. In the formulation of water quality index, the importance of various parameters depends on the intended use of water; here water quality parameters are studied from the point of view of suitability for human consumption. The "standards" (permissible values of various pollutants) for the drinking water, recommended by the Indian Council of Medical Research [59], United States Public Health Services [60], World Health Organization [61], Indian Standards Institution [62], and unit weights are given in Table 5. For the purpose of the present investigation, twelve water quality parameters have been selected.

Water quality index is

$$
\mathrm{WQI}=\frac{\sum_{i=1}^{13} q_{i} w_{i}}{\sum_{i=1}^{13} W_{i}}
$$

which gives

$$
\begin{gathered}
\text { WQI }=\sum_{i=1}^{13} q_{i} w_{i}, \\
\text { Since } \sum W_{i}=1,
\end{gathered}
$$

where $q_{i}$ (water quality rating) $=100 \times\left(V_{a}-V_{i}\right) /\left(V_{s}-V_{i}\right)$. 
When $V_{a}$ is the actual value present in the water sample, $V_{i}$ is the ideal value ( 0 for all parameters except $\mathrm{pH}$ and $\mathrm{DO}$ which are 7.0 and $14.6 \mathrm{mg} \mathrm{L}^{-1}$, resp.). $V_{s}$ is the standard value.

Pollutants are: (i) completely absent when $q_{i}=0$, (ii) with in prescribed standard values when $0<q_{i}<100$, and (iii) are above standard values when $q i>100$.

The more harmful a given pollutant is, the smaller is its permissible value for drinking water. So the "weights" for various water quality parameters are assumed to be inversely proportional to the recommended standards for the corresponding parameters; that is,

$$
W_{i}=\frac{k}{S_{n}},
$$

where $W_{i}$ is the unit weight for the $i$ th parameter $(i=$ $1,2,3, \ldots, 12$ ),

$k$ is the constant of proportionality which is determined from the condition, and $k=1$ for sake of simplicity.

$S_{n}$ is the " $n$ " number of standard values.

Based on the range of WQI values, water is grouped into the following categories [27]:

(I) WQI less than 25: water is not polluted and fit for human consumption (excellent),

(II) WQI between 26 and 50: slightly polluted (good),

(III) WQI between 51 and 75: moderately polluted (poor),

(IV) WQI between 76 and 100: polluted (very poor),

(V) WQI above 100: excessively polluted and unfit for human use (unsuitable).

In this study, multivariate statistical and mathematical analysis methods (DA and WQI approaches) were applied to evaluate the impact of anthropogenic activities and spatiotemporal variations in physicochemical characteristics on water quality of Wular Lake. Statistical conclusions and tests were made on the basis of a multiparametric model, specifying how water quality parameters are changed with different seasons and nature of polluting source in the studied aquatic system.

\section{Results and Discussion}

3.1. Physicochemical Parameters. During the two years of this study, the lake behavior was explored by measuring 27 parameters to assess the quality of this aquatic system. All these parameters were measured from samples collected from study stations in the Wular Lake, as indicated in Figure 1. The mean and standard deviation and range of water quality parameters of five study sites are presented in Figures 2(a), 2(b), 2(c), and 2(d). Box and whisker plots showed the whole spatiotemporal dynamics of physical, chemical, nutrient, and ionic parameters of two-year study carried out in Wular Lake. The high standard deviation of most parameters indicates presence of temporal and spatial variations caused likely by polluting sources and/or climatic factors [25]. Mean water temperature was strongly seasonal and ranged from a minimum of $4.2^{\circ} \mathrm{C}$ in winter to a maximum of $25.6^{\circ} \mathrm{C}$ in summer.
The water temperature reflects the atmospheric temperature, and it presents the most significant difference among seasons. Throughout the year, mean transparency ranged from 0.86 to $1.15 \mathrm{~m}$. The sites nearer to inflows showed lower depth than those nearer to outflow. The low transparency value in some of the high altitude Kashmir Himalayan water bodies has been attributed to the incoming silt from the catchment [63]. Seasonally, the highest value of water transparency occurred in winter at all sampling sites and may be attributed to low suspended organic matter with poor planktonic growth [64]. The highest average TDS content was recorded mainly at the site I $(154.11 \pm 32.2)$ located in the proximity of major inflow of the lake. Seasonal variation was also observed in TDS, with lower values in dry season (autumn) and higher values in rainy season (spring). From the temperature difference, changes are expected in DO. As expected, dissolved oxygen is negatively related to temperature because the solubility of oxygen in water decreases with increasing temperature [65]. The highest average $\mathrm{pH}(7.84 \pm 0.34)$ was recorded at the site located in the proximity of major tributary. Mean $\mathrm{pH}$ of water body, ranging from 7.2 to 8.5 , showed a significant temporal variation. $\mathrm{pH}$ recorded in the present study was in alkaline range suggesting that the lakes were well buffered throughout the study period. $\mathrm{pH}$ range from 7.2 to 8.5 indicates productive nature of water body [66]. Throughout the year, EC varied between 100 and $387 \mu \mathrm{S} \mathrm{cm}^{-1}$. Seasonally, EC was lower in spring and summer than in autumn and winter seasons. Spring-summer minima were due to nutrient assimilation by autotrophs [67]. The lake exhibited higher value of EC which reflects the high degree of anthropogenic activities such as waste disposal and agricultural runoff. The distribution of DO among sampling seasons showed marked temporal variability and its lower value in summer $\left(7.8 \pm 0.19 \mathrm{mg} \mathrm{L}^{-1}\right)$ and higher $\left(10.1 \pm 0.16 \mathrm{mg} \mathrm{L}^{-1}\right)$ in winter season. The inverse relationship between temperature and dissolved oxygen is a natural process because warmer water becomes more easily saturated with oxygen and it can hold less dissolved oxygen [23]. In winter, the highest free $\mathrm{CO}_{2}$ was recorded at sites III and IV, whereas in spring it was the highest at site VI. Decreased $\mathrm{CO}_{2}$ level in summer season indicates the consumption of $\mathrm{CO}_{2}$ due to high rates of photosynthesis by autotrophs there by reducing $\mathrm{pH}$ [68]. Clear seasonal trend was found in hardness at all sampling sites. The alkalinity showed fluctuations between stations with the highest average vales $(10.04 \pm 3.17$ and $10.43 \pm$ $3.31 \mathrm{mg} \mathrm{L}^{-1}$ ) at sites IV and V. In general, the highest and the lowest $\mathrm{NO}_{3}-\mathrm{N}$ concentrations occurred in winter and summer, respectively. The sites located close to inlets showed higher $\mathrm{NO}_{3}-\mathrm{N}$ concentrations compared to sites near outlet channel throughout the study period. The seasonal variations of nitrate concentration in the lake were similar to the patterns generally reported in other water bodies, where nitrate levels are higher in winter than in summer, due to a decreased biological activity (bacterial denitrification and algal assimilation) in winter [69]. $\mathrm{NO}_{2}-\mathrm{N}$ and organic- $\mathrm{N}$, being influenced by temperature, maintained higher values in summer and lower in winter season. The $\mathrm{NH}_{3}-\mathrm{N}$ concentration showed similar temporal pattern to $\mathrm{NO}_{3}-\mathrm{N}$ 


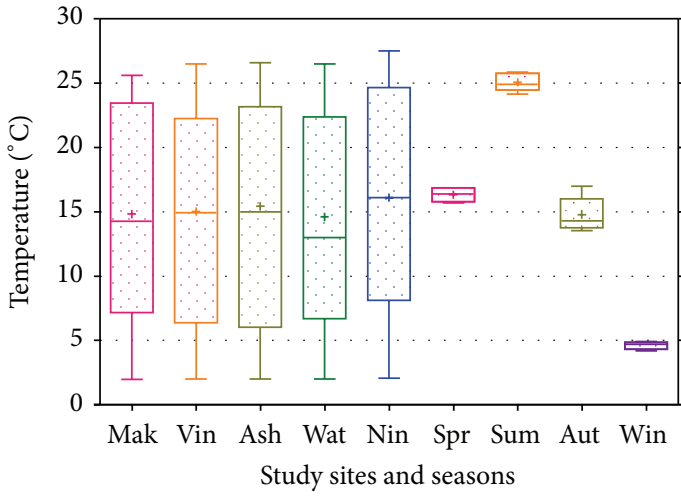

(i)

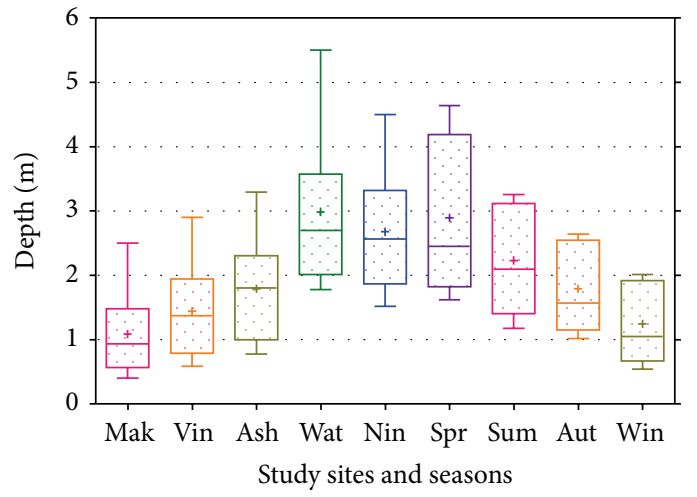

(ii)

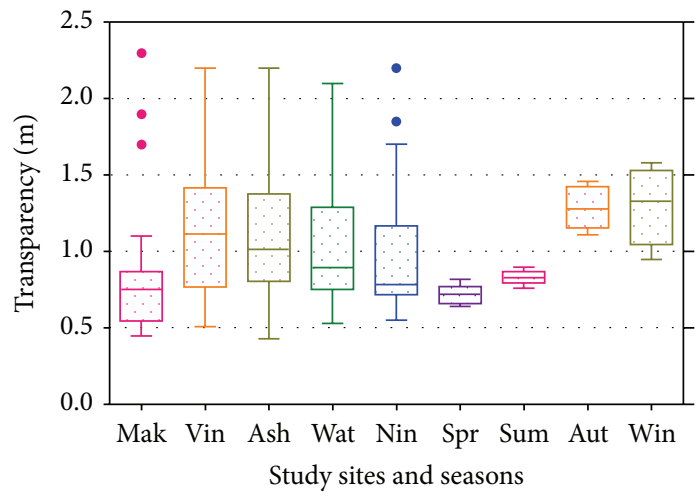

(iii)

(a)

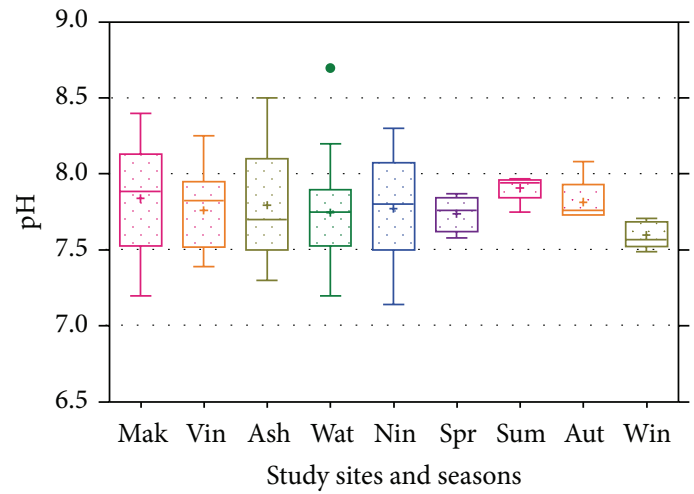

(i)

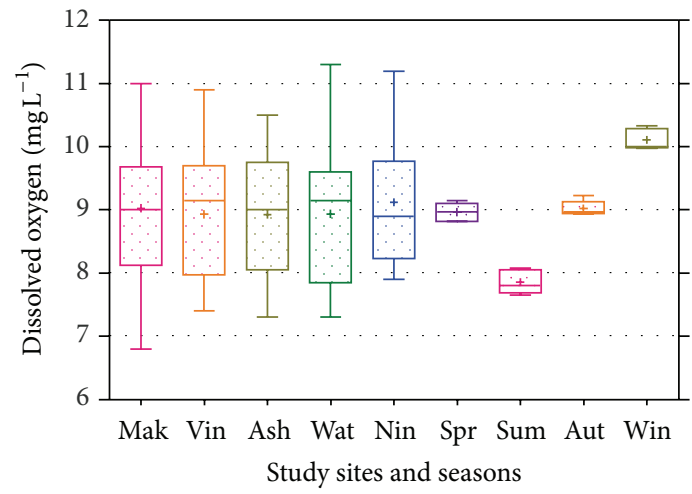

(iii)

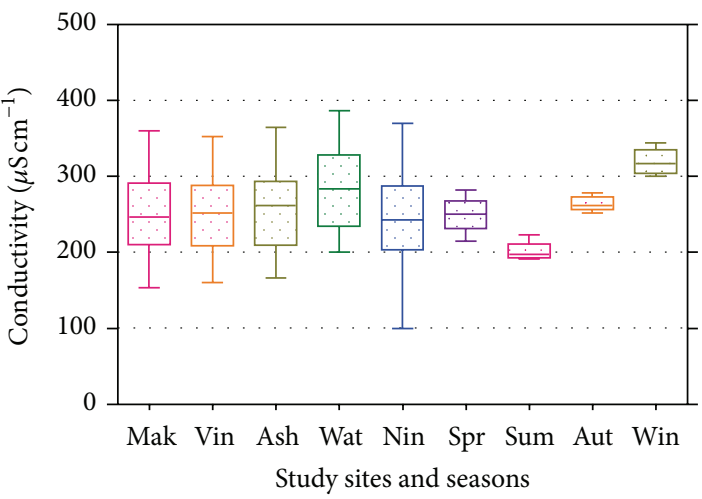

(iii)

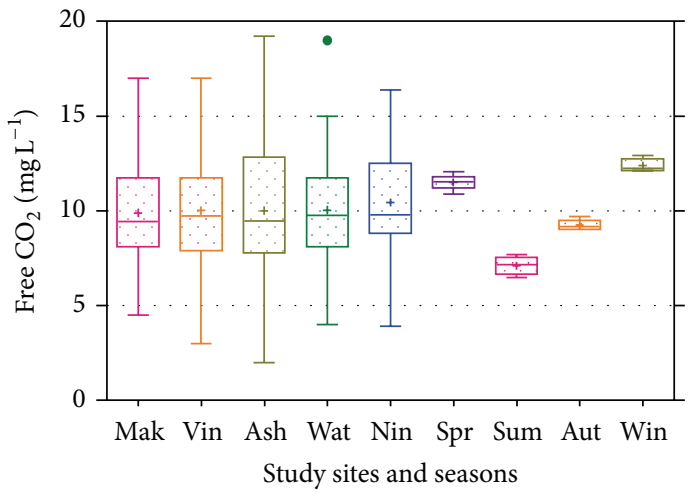

(iv)

(b) Continued

Figure 2: Continued. 


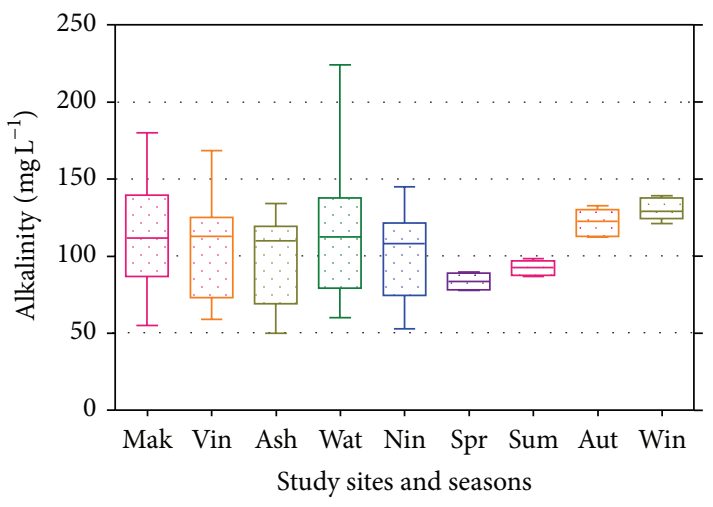

(v)

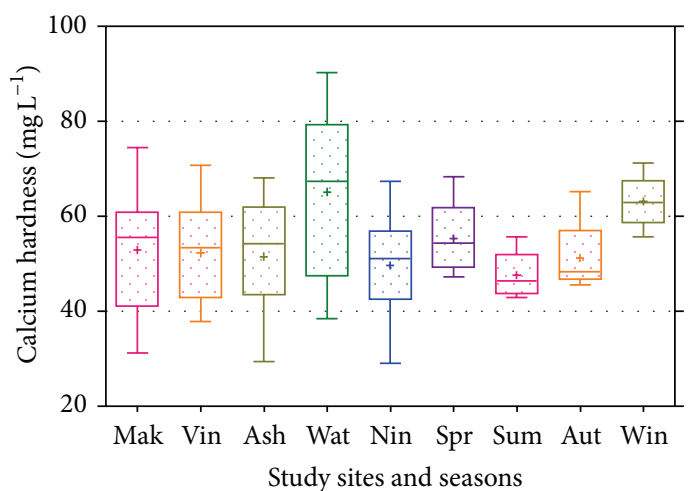

(vii)

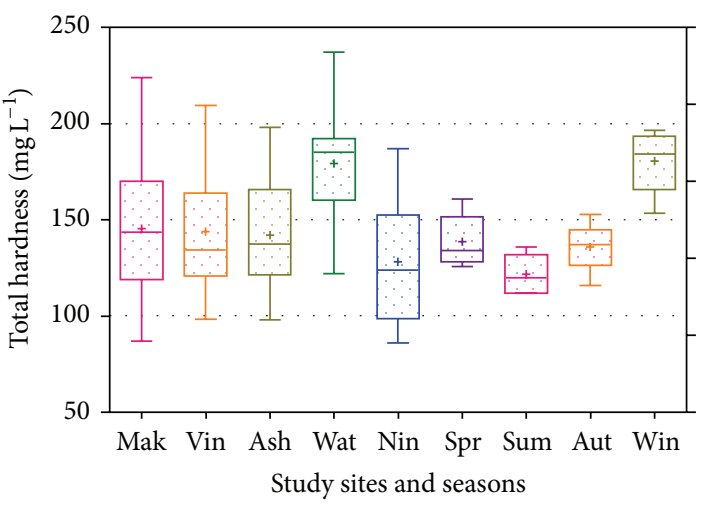

(vi)

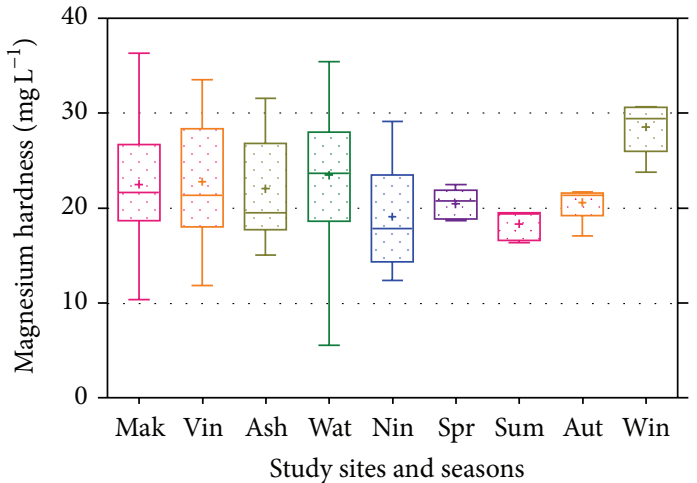

(viii)

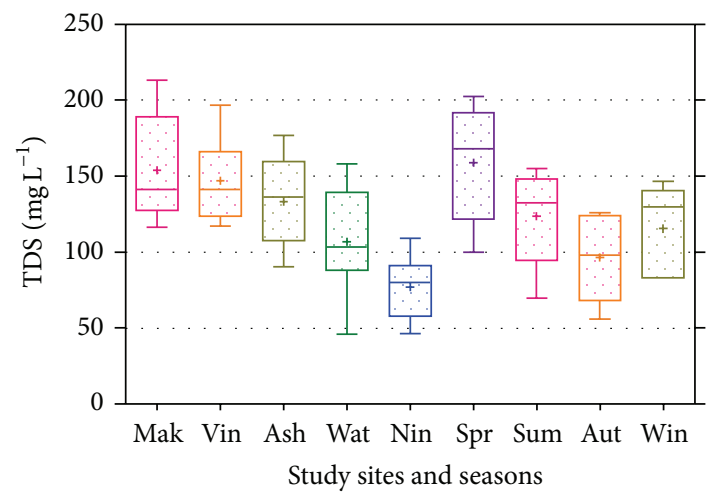

(ix)

(b)

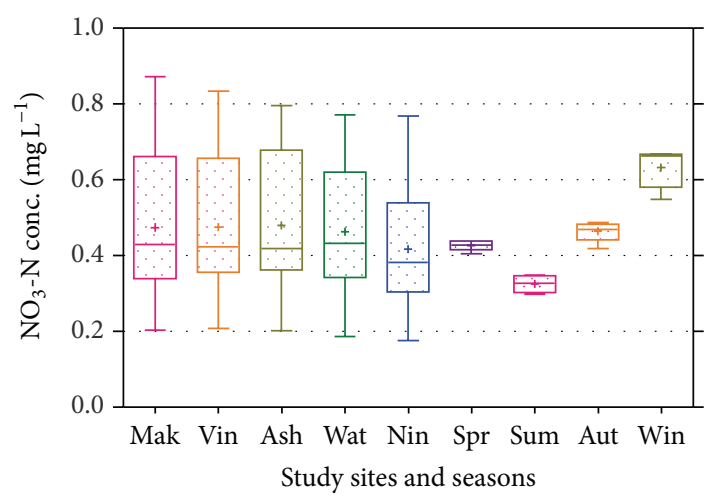

(xiii)

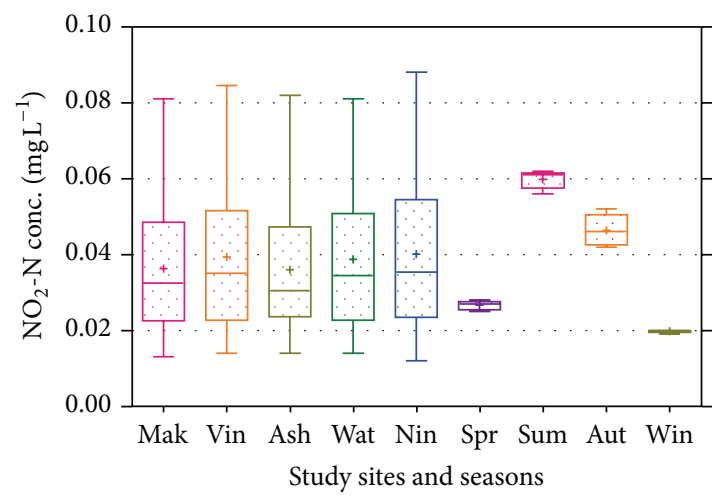

(xiv)

(c) Continued

FIgure 2: Continued. 


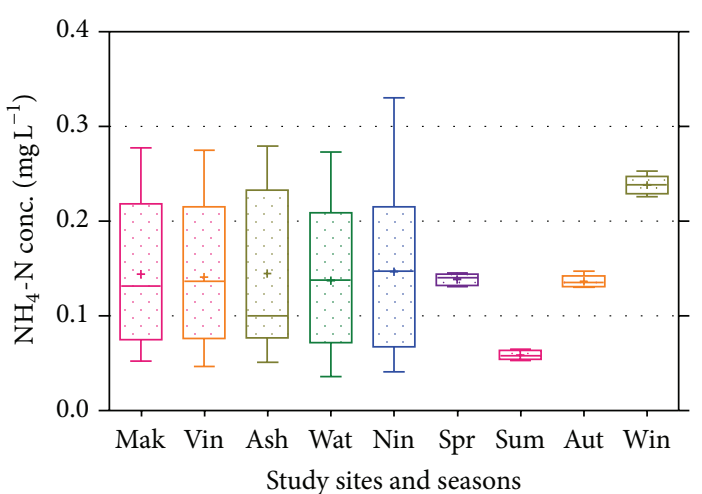

(xv)

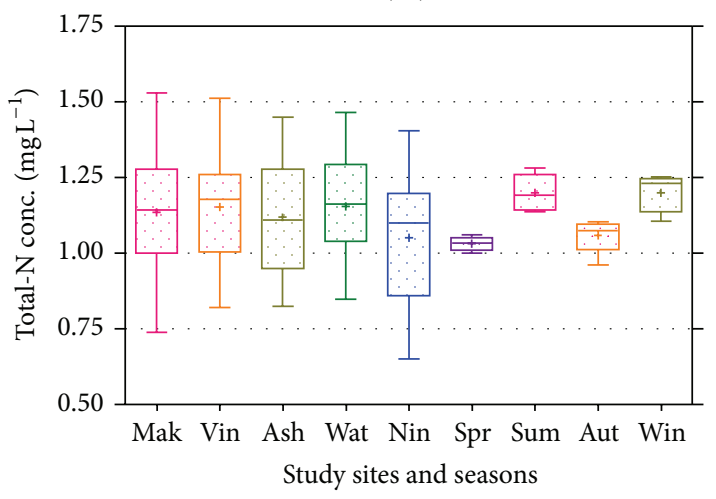

(xvii)

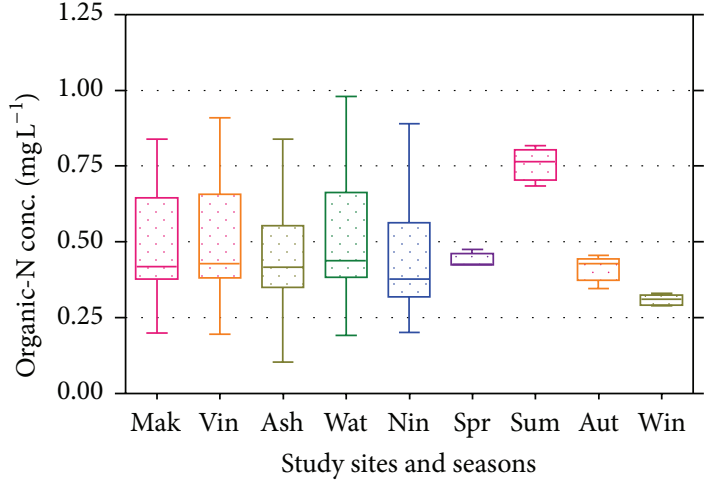

(xvi)

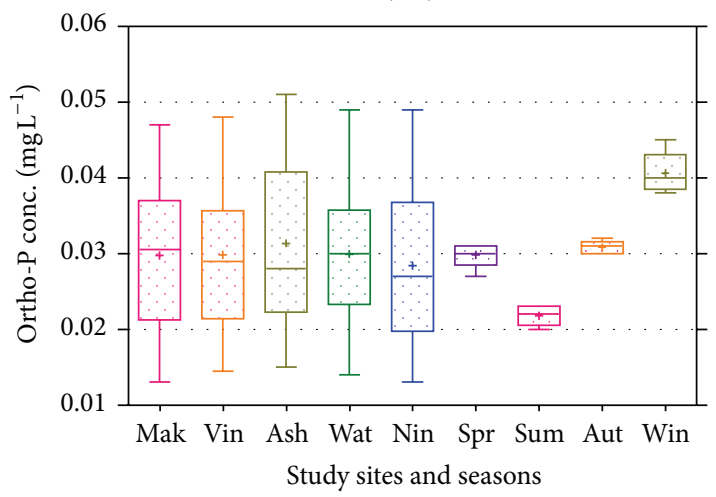

(xviii)

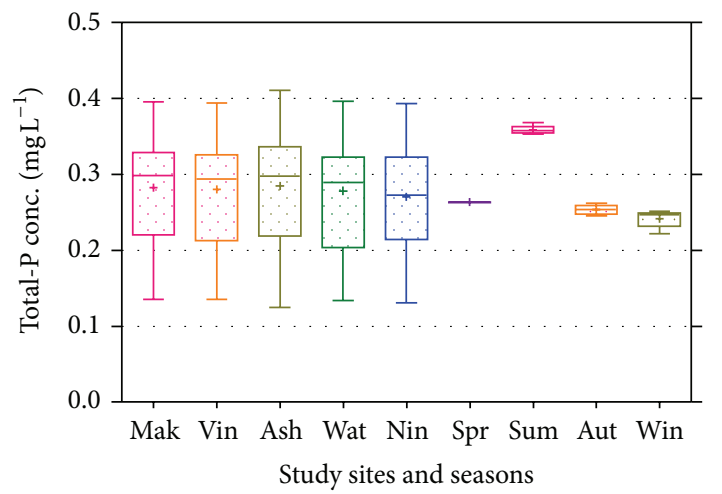

(xix)

(c)

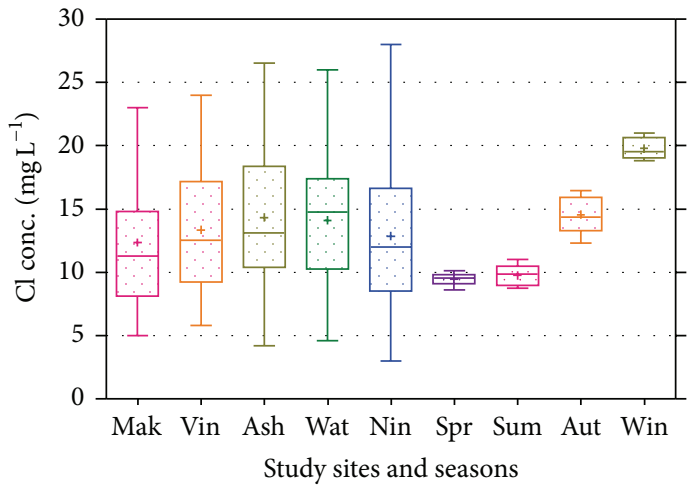

(i)

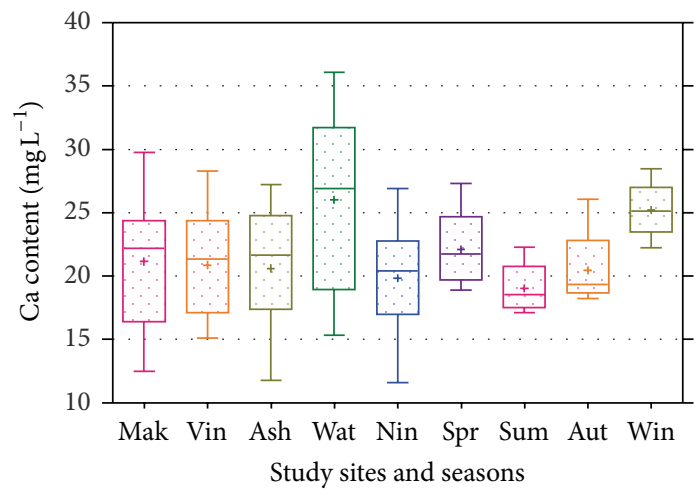

(ii)

(d) Continued

Figure 2: Continued. 


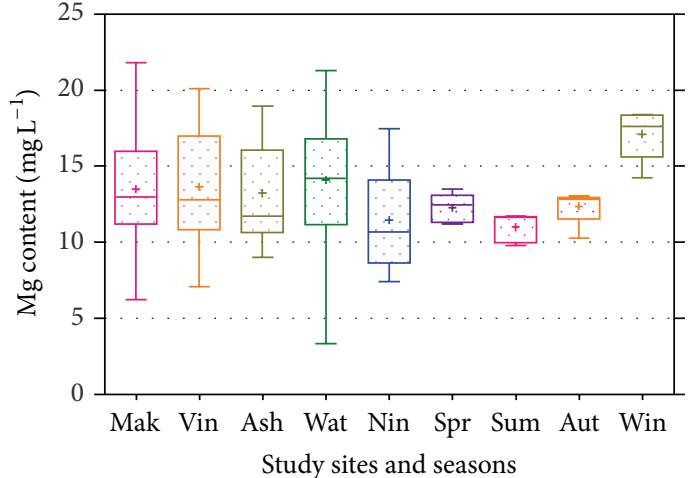

(iii)

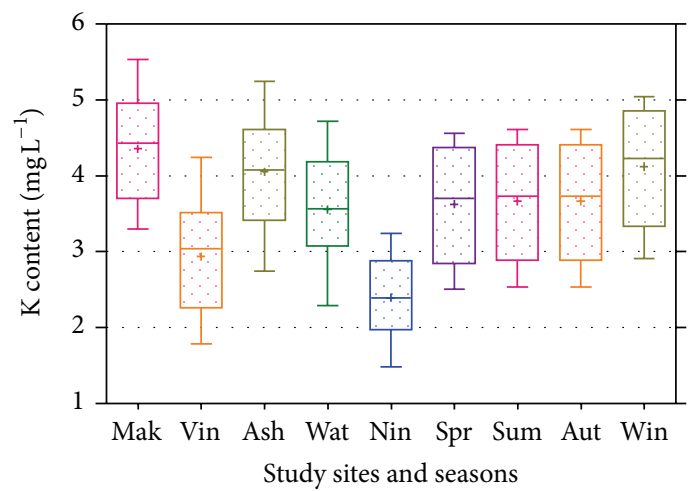

(v)

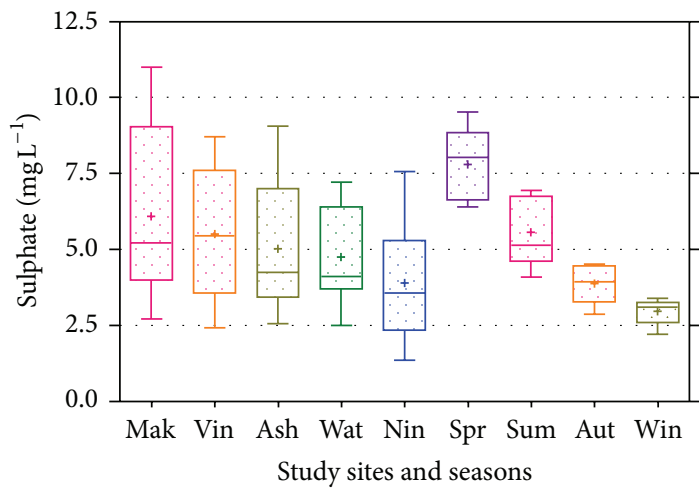

(vii)

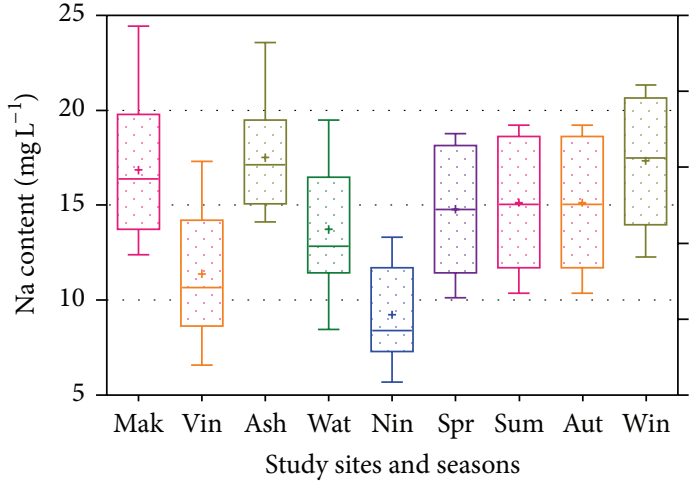

(iv)

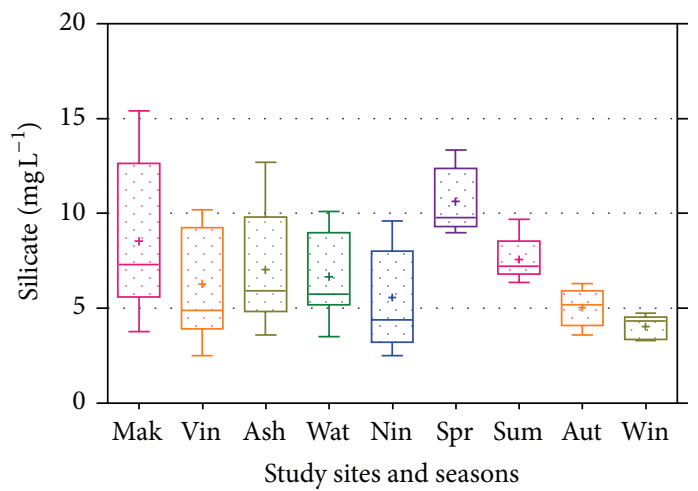

(vi)

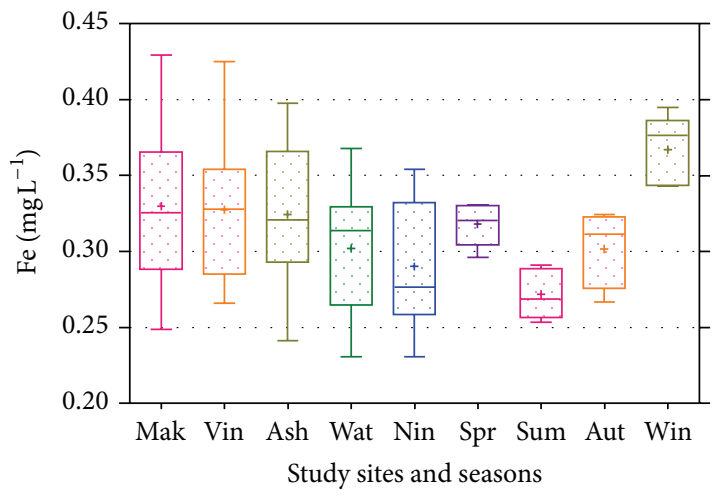

(viii)

(d)

Figure 2: (a) Box and whisker plots showing spatiotemporal dynamics of physical parameters. (b) Box and whisker plots showing spatiotemporal dynamics of chemical parameters. (c) Box and whisker plots showing spatiotemporal dynamics of nutrient ( $\mathrm{N}$ and $\mathrm{P}$ ) parameters. (d) Box and whisker plots showing spatiotemporal dynamics of ionic parameters.

concentration, with high values in spring and winter and low values in summer and autumn. Nitrate may originate from livestock wastes, fertilizers, and nonpoint sources of pollution, such as runoff from agriculture areas [70]. The sites located close to rural residential area showed higher mean total- $\mathrm{N}$ concentration mainly in summer season. It has been reported that $\mathrm{N}$ fertilizer applied to farmland is the main source of $\mathrm{N}$ pollution in surface water [71, 72]. The distribution of ortho-P showed significant variation with average higher values $(0.04 \pm 0.002)$ in winter contrary to average lower values $(0.02 \pm 0.001)$ in summer season. Ortho-P enters the lakes through domestic wastewater and agricultural runoff, accounting for the accelerated eutrophication [73]. The sites influenced by agriculture and domestic sewage (sites I, II, and III) showed high TP concentrations during all the year, with relatively high values in spring and summer and low values in autumn and winter. It has been documented by [74] that municipal wastewater contains substantial amount of phosphorus contributed by human urine and detergents. Increased concentration of phosphorus and $\mathrm{NO}_{3}-\mathrm{N}$ in lakes has resulted in enhanced productivity elevating oxygen demand in turn $[46,75]$. However, besides its contribution to eutrophication and toxic algal blooms, phosphate does not have notable adverse health effects [61]. 
The highest value of chloride content $\left(19.7 \pm 0.85 \mathrm{mg} \mathrm{L}^{-1}\right)$ was reported in winter season at all sampling sites. Chloride concentration was higher in winter season due to poor dilution of wastewater because sodium chloride, a common component of the human diet, passes unchanged through the digestive system [61]. Cations maintained higher concentration in winter season and in contrast to those of anions, which showed lower concentration in winter season. Spatially and temporally $\mathrm{Ca}$ and $\mathrm{Mg}$ content was the highest at site IV and in winter season, respectively. $\mathrm{Ca}$ and $\mathrm{Mg}$ rich water in Kashmir valley is attributed to the predominance of lime rich rocks in the catchment area [76]. Throughout the year, the lowest content of $\mathrm{Na}$ and $\mathrm{K}$ occurred at site $\mathrm{V}$, with concentrations ranging from 5.6 to 13.3 and from 1.4 to $3.2 \mathrm{mg} \mathrm{L}^{-1}$, respectively. Domestic sewage is the responsible factor for higher content of sodium and potassium in freshwaters [77]. Silicate maintained continuous decreasing trend from spring to winter season with maximum average values at site I (8.53 $\left.\pm 3.74 \mathrm{mg} \mathrm{L}^{-1}\right)$ throughout the study period. Silicate exports from land-based resources, especially during rainfall [78]. Sulphate distribution showed similar spatial trend to silicate, with high values at site I $\left(6.09 \pm 2.67 \mathrm{mg} \mathrm{L}^{-1}\right)$ and low values at other stations. The high sulphate content found in water is probably a consequence of the morphology of soils irrigated by the river, which are formed mainly by limestone, marl, and gypsum [25]. Seasonally, the higher concentration of iron was reported in winter season against the lower values in summer at all of the study sites. The water-quality data (3240 observations) was further subjected to different multivariate statistical techniques to explore their temporal and spatial trends.

3.2. Discriminant Analysis. Discriminant analysis is one of the more advanced multivariate classification techniques used to define the variables, discriminating between the identified clusters, by specifying the weight (i.e., discriminating power) to these variables $[79,80]$.

Spatial variations in water parameters were evaluated through stepwise discriminant analysis (DA) method. Four discriminant functions (DFs) were found to discriminate the quality of the five sampling sites used in this study (Table 3). Wilks Lambda test showed that all five functions were statistically significant $(P<0.05)$. Furthermore, 95.6\% of the total variance between the five sampling sites was accounted for by the first two DFs. The first DF accounted for $76.5 \%$ of the total spatial variance, and the second DF accounted for $19.1 \%$. The relative contribution of each parameter is given in Table 3 . The mean values of water temperature, EC, total-N, K, and silicate showed a strong contribution in discriminating the five sampling sites and accounted for most of the expected spatial variations in the lake, while other parameters exhibited a low contribution to the discriminant function. The second group of parameters (DF2) that accounted for the remaining spatial variations was mean concentration of organic- $\mathrm{N}$ and $\mathrm{Na}$ (Table 3 ).

From the canonical discriminant plot (Figure 3), the sampling stations close to major tributaries (I and II) showed high positive loadings for factors represented by the first discriminant function (DF1) indicating that these study points were highly characterized by elevated levels of EC, K and silicate. The spatial discriminating function showed varying nature of water quality factors (EC, TN, K, Org.- N, Na, etc.) at different study sites and is due to dynamic nature of natural and anthropogenic influences active in lake catchment. The sites located away from inflow, that is, IV and $\mathrm{V}$ depicted negative associations with these factors indicating that these sites were characterized by minimal levels of these chemical contaminants. On the other hand, the site IV showed high positive loadings for the factors represented by the second discriminant function (DF2) indicating that the site was characterized by elevated levels of organic- $\mathrm{N}$ and $\mathrm{Na}$ compared to sites I and II. The higher loading values of EC, Na, K, and organic- $\mathrm{N}$ indicate the impact of enhanced organic matter load imported via domestic wastewater [23]. The higher value of EC at some study stations is attributed to the high degree of anthropogenic activities such as waste disposal and agricultural runoff. Further positive loading of $\mathrm{Na}^{+}$is attributed to agricultural runoff [81], while asserted variations of $\mathrm{K}$ are linked with parent rock materials present in the catchment area [76].

Temporal DA was performed on synthesized data after dividing the whole data set into four seasonal groups (spring, summer, autumn, and winter). Three discriminant functions (DFs) were found to discriminate the quality of the three sampling seasons used in this study (Table 4). Wilks Lambda test showed that all three functions were statistically significant $(P<0.05)$. Furthermore, $94.8 \%$ of the total variance between the four sampling seasons was accounted for by the first two DFs. The first DF accounted for $85.5 \%$ of the total temporal variance, and the second DF accounted for $8.8 \%$. The relative contribution of each parameter is given in Table 4 . The mean concentration of $\mathrm{NO}_{2}-\mathrm{N}$, total- $\mathrm{N}$, and sulphate showed a strong contribution in discriminating the four sampling seasons and accounted for most of the expected seasonal variations in the lake, while other parameters exhibited a low contribution to the discriminant function. The second group of parameters (DF2) that accounted for the remaining spatial variations was mean concentration of $\mathrm{NH}_{4}-\mathrm{N}$ and TDS (Table 4). Table 4 presents the standardized function coefficients, which highlight the parameters that exhibited the highest change across seasons.

Discriminant plot for temporal variations (Figure 4) showed that the spring season and summer season were strongly characterized by increased $\mathrm{NO}_{2}-\mathrm{N}$, total-N, and sulphate while $\mathrm{NH}_{4}-\mathrm{N}$ and TDS had respective strong positive and negative associations with the autumn season and winter season. The average concentrations of $\mathrm{NO}_{2}-\mathrm{N}$, total$\mathrm{N}$, and sulphate were higher in summer and spring compared to autumn and winter. This may be due to tributary inputs and surface runoff, which carry more nutrients into the lake during the rainy season (spring and summer). Depth increases with higher runoff, which in turn brings higher load of nitrate from this agriculture dominated watershed in spring and summer seasons. Nitrate is more associated with the use of organic and inorganic fertilizers [82, 83]. Positive loading on total- $\mathrm{N}$ has been associated with agricultural runoff [84]. 


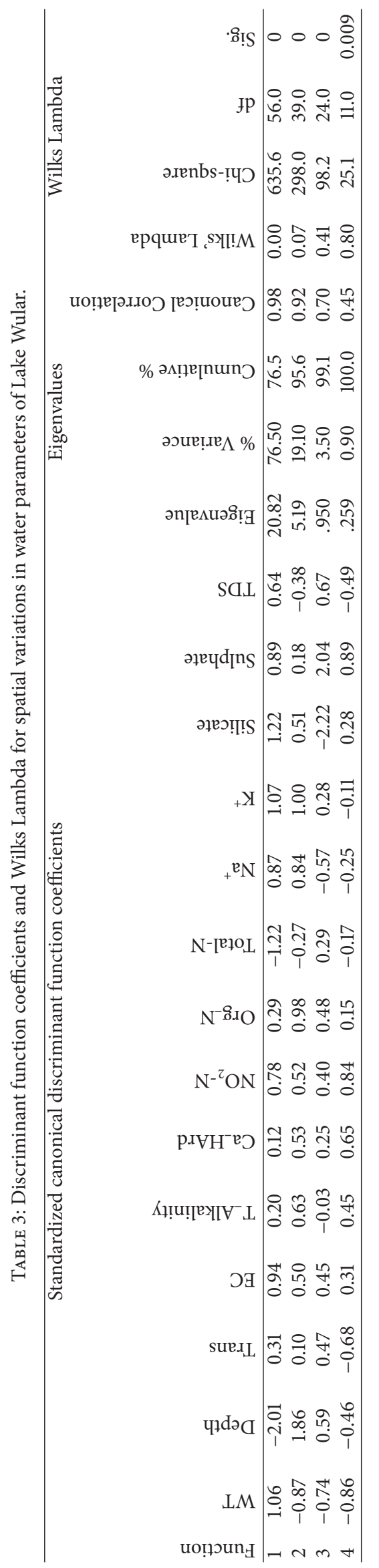




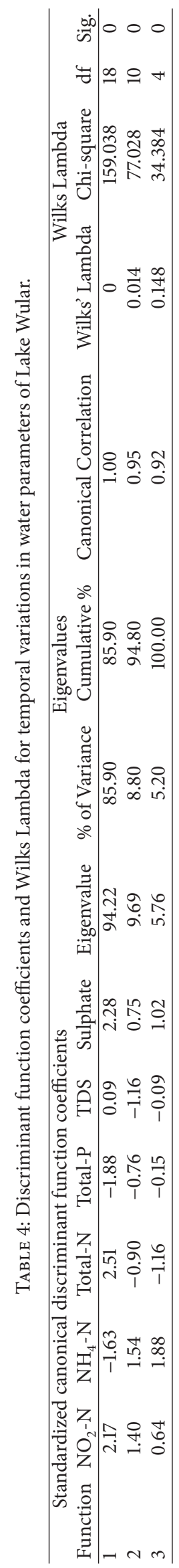




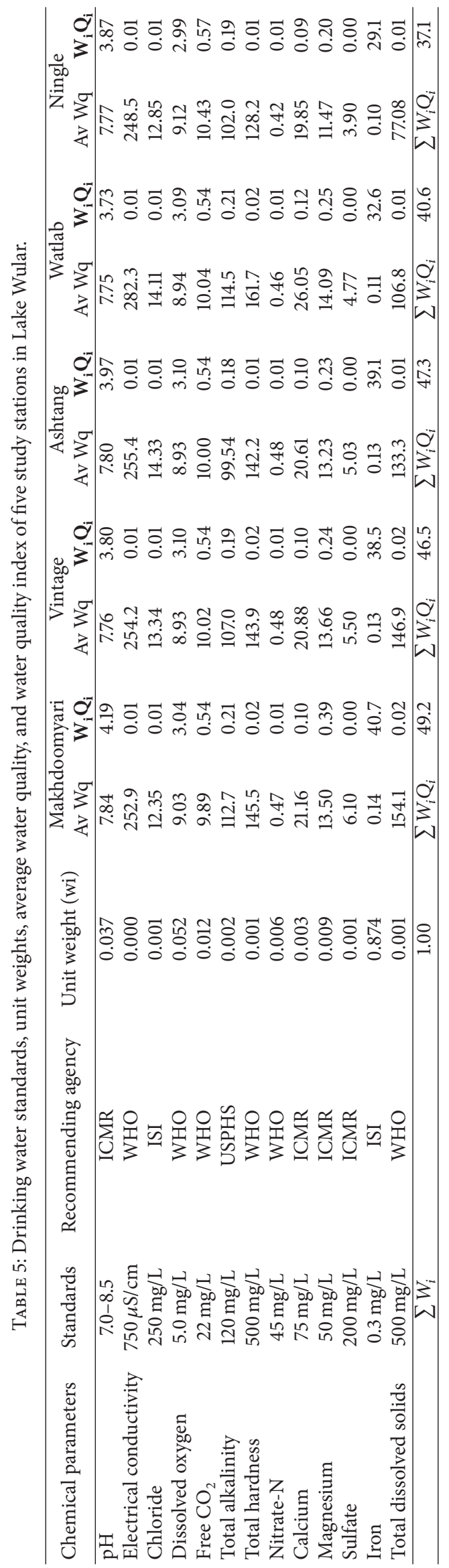




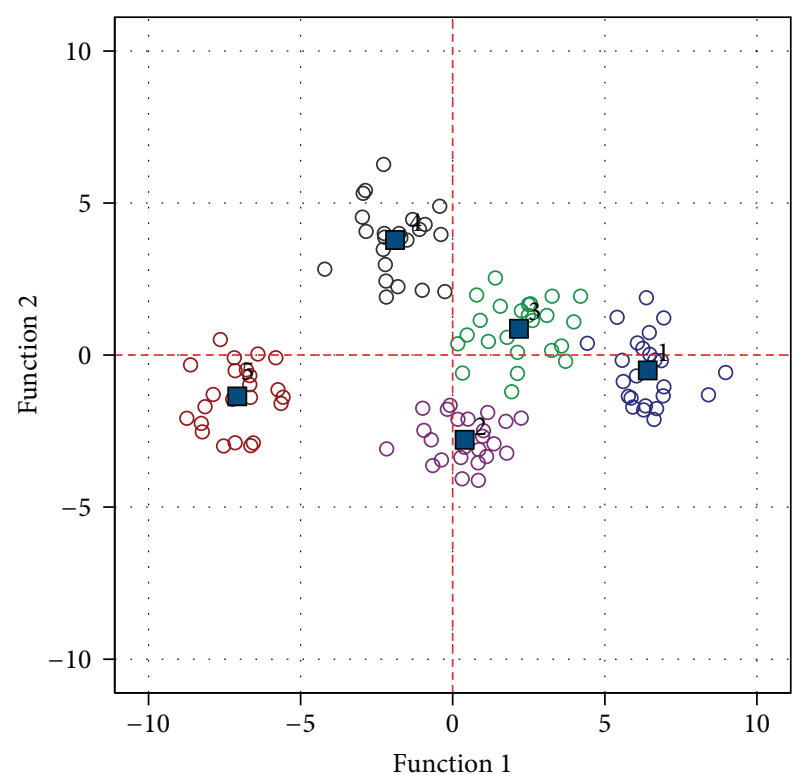

Sample station
1-Makhdoomyari
2-Vintage
3-Ashtang

4-Watlab

5-Ningle

$\square$ Group centroid

FIGURE 3: Discriminant plot showing spatial variation of water parameters in Lake Wular (2012-2003).

3.3. Water Quality Index. Evaluation of overall water quality is not an easy task, particularly when different criteria for different uses are applied. Moreover, the classification of water quality follows various definitions with respect to the contents of different water quality parameters. Dozens of variables have been developed and are available to be used in management governmental or environmental programs, but the high price because of water analysis to attend these programs generally makes it difficult to use them. In this study, the application of the water quality index approach to the Lake Wular has the objective of providing a simple and valid method for expressing the results of several parameters in order to more rapidly and conveniently assess the water quality. Combining different parameters into one single number leads to an easy interpretation of the index, thus providing an important tool for management purposes. As described, WQI employing thirteen parameters can give an indication of the health of the water body at various points and can be used to keep track of and analyze changes over time, but other options can be used in an economic way.

The values of water quality indices are taken as the standards for drinking water according to Table 5. The results of water quality index employing thirteen parameters showed values of $49.2,46.5,47.3,40.6$, and 37.1 for sites I, II, III, IV, and V, respectively. The status of water corresponding to the WQI is categorized into five types which is given in Table 5. From the table, it is evident that the surface water samples of studied lake are falling under good category. However, the quality of samples collected from the lake is high in case of stations located near to lake tributaries
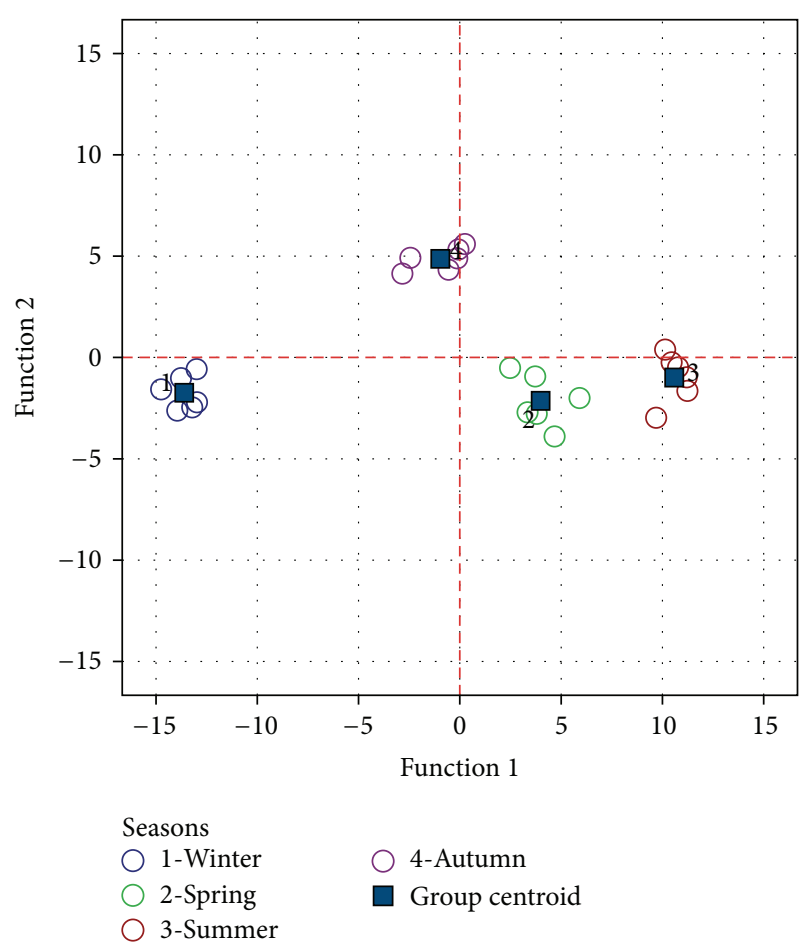

FIGURE 4: Discriminant plot showing temporal variation of water parameters in Lake Wular (2012-2013).

indicating high pollution. In these cases, high WQI is mainly due to the presence of high concentration of Iron and other parameters. WQI analysis showed that the water of lake is in good condition for drinking purpose but increased values warn us about future consequences.

Ionic Composition. The order of major cations and anions was $\mathrm{Ca}^{2+}>\mathrm{Mg}^{2+}>\mathrm{Na}^{+}>\mathrm{K}^{+}$and $\mathrm{Cl}^{-}>\mathrm{SO}^{2-}>$ $\mathrm{SiO}_{2}{ }^{2-}$ respectively. This pattern also shows that the lake water is dominated by alkaline earth $\mathrm{Ca}$ and $\mathrm{Mg}\left(\mathrm{Ca}^{2+}\right.$ and $\mathrm{Mg}^{2+}$ ) and weak acids. Dominance of $\mathrm{Ca}$ and $\mathrm{Mg}$ ions in lake water is linked primarily with parent rock material present in the catchment area [85]. It is also apparent that the dominance of $\mathrm{Cl}^{-}$over $\mathrm{SO} 4{ }^{2-}$ could be due to the large amount of domestic and sewage water being discharged into tributary waters [86]. The primary source of major ions in the river and lake waters is atmospheric deposition, dissolution of evaporates (halite, gypsum), and weathering of carbonates and silicates by sulphuric acid or carbonic acid and anthropogenic activities. $\mathrm{Ca}, \mathrm{Mg}$, and $\mathrm{HCO}_{3}$ are derived from weathering of carbonates rocks by carbonic acid $[87,88]$ as the carbonate rocks weather congruently. Magnesium is often associated with calcium in all kinds of waters, but its concentration remains generally lower than the calcium [89]. Water hardness contains dissolved metals like $\mathrm{Mg}$, originated from agricultural and domestic sewage, seen in high levels, therefore revealing instances of soil weathering, erosion (seasonal effect) and anthropogenic sources of pollution in this area. Magnesium is essential for chlorophyll growth and acts as a limiting factor for the growth of phytoplankton [90]. Like 
the "standard" freshwater, in which calcium is the dominating cation [91], the ionic composition of the water in Wular Lake was also dominated by calcium followed by magnesium. The chemical denudation due to dilution from heavy rains coupled with the reservoir circulation and weathering from rock and runoffs from surrounding watersheds might have contributed to the availability of calcium and magnesium ions. $\mathrm{Ca}$ and $\mathrm{Mg}$ concentration of freshwater bodies of Kashmir Himalaya has been associated with thick population of plankton, especially Cyanophyceae [92]. The presence of calcium and magnesium ions in moderate levels classifies the reservoir as eutrophic which will support diverse plant and animal life including fish. According to [93], waters with calcium levels of $<10 \mathrm{mg} \mathrm{L}^{-1}$ are usually oligotrophic, while those above $25 \mathrm{mg} \mathrm{L}^{-1}$ are eutrophic.

\section{Conclusion}

In this study, statistical and mathematical exploratory techniques were utilized to evaluate variations in surface water quality of Lake Wular. This study has shown that the highest sources of variation in water quality are both seasonal factors as well as anthropogenic factors. The results exhibit that the DA technique is useful in present accredited classification of surface waters in the whole lake basin; hence, the number of sampling sites and respective cost in the future monitoring plans can be lessen. The water quality index provided a numeric expression, used to transform large number of variables data into a single number, which represented the water quality level of whole Wular Lake basin. Thus, the study illustrates the useful application of chemometric techniques for the analysis and interpretation of lake water quality data and identification based on pollution status and identification of pollution sources as part of the efforts towards management of sustainability of this lake. The main sources of pollution came from domestic wastewater and agricultural activities and runoff; however, they contributed differently to each station in regard to pollution levels. These results provide fundamental information for developing better water pollution control strategies for the Wular Lake.

\section{Conflict of Interests}

The authors declare that there is no conflict of interests regarding the publication of this paper.

\section{Acknowledgments}

The authors are indebted to Director, Centre of Research for Development (CORD), and Head Department of Environmental Science, University of Kashmir, for providing full support and necessary laboratory facilities for carrying out the chemical analysis. Also the authors gratefully acknowledge the help from the State Irrigation and Flood Control and Indian Meteorological Department for providing necessary data.

\section{References}

[1] H. P. Jarvie, B. A. Whitton, and C. Neal, "Nitrogen and phosphorus in east coast British rivers: speciation, sources and biological significance," Science of the Total Environment, vol. 210-211, pp. 79-109, 1998.

[2] S. Ravichandran, "Hydrological influences on the water quality trends in Tamiraparani basin, South India," Environmental Monitoring and Assessment, vol. 87, no. 3, pp. 293-309, 2003.

[3] A. H. Mahvi, J. Nouri, A. A. Babaei, and R. Nabizadeh, "Agricultural activities impact on groundwater nitrate pollution," International Journal of Environmental Science and Technology, vol. 2, no. 1, pp. 41-47, 2005.

[4] S. Liao, H. Gau, W. Lai, J. Chen, and C. Lee, "Identification of pollution of Tapeng Lagoon from neighbouring rivers using multivariate statistical method," Journal of Environmental Management, vol. 88, no. 2, pp. 286-292, 2008.

[5] N. Gantidis, M. Pervolarakis, and K. Fytianos, "Assessment of the quality characteristics of two lakes (Koronia and Volvi) of N. Greece," Environmental Monitoring and Assessment, vol. 125, no. 1-3, pp. 175-181, 2007.

[6] M. B. Arain, T. G. Kazi, M. K. Jamali, N. Jalbani, H. I. Afridi, and A. Shah, "Total dissolved and bioavailable elements in water and sediment samples and their accumulation in Oreochromis mossambicus of polluted Manchar Lake," Chemosphere, vol. 70, no. 10, pp. 1845-1856, 2008.

[7] A. A. Olajire and F. E. Imeokparia, "Water quality assessment of Osun river: Studies on inorganic nutrients," Environmental Monitoring and Assessment, vol. 69, no. 1, pp. 17-28, 2001.

[8] J. C. Vie, C. Hilton-Taylor, and S. N. Stuart, Eds., Wildlife in a Changing World-An Analysis of the 2008, IUCN Red List of Threatened Species, IUCN, Gland, Switzerland, 2009.

[9] K. E. Murray, S. M. Thomas, and A. A. Bodour, "Prioritizing research for trace pollutants and emerging contaminants in the freshwater environment," Environmental Pollution, vol. 158, no. 12, pp. 3462-3471, 2010.

[10] W. D. Alberto, D. M. Del Pilar, A. M. Valeria, P. S. Fabiana, H. A. Cecilia, and B. M. De Los Angeles, "Pattern recognition techniques for the evaluation of spatial and temporal variations in water quality. A case study: Suquía River Basin (CordobaArgentina)," Water Research, vol. 35, pp. 2881-2894, 2001.

[11] V. Simeonov, J. A. Stratis, C. Samara et al., "Assessment of the surface water quality in Northern Greece," Water Research, vol. 37, no. 17, pp. 4119-4124, 2003.

[12] K. P. Singh, A. Malik, D. Mohan, and S. Sinha, "Multivariate statistical techniques for the evaluation of spatial and temporal variations in water quality of Gomti River (India): a case study," Water Research, vol. 38, no. 18, pp. 3980-3992, 2004.

[13] A. Qadir, R. N. Malik, and S. Z. Husain, "Spatio-temporal variations in water quality of Nullah Aik-tributary of the river Chenab, Pakistan," Environmental Monitoring and Assessment, vol. 140, no. 1-3, pp. 43-59, 2008.

[14] J. R. Chinhanga, "Impact of industrial effluent from an iron and steel company on the physico-chemical quality of Kwekwe River water in Zimbabwe," International Journal of Engineering, Science and Technology, vol. 2, no. 7, pp. 29-40, 2010.

[15] United States Environmental Protection Agency, Re-cent Recommended Water Quality Criteria, United States Environmental Protection Agency, 2007, http://www.epa.gov/waterscience/criteria/wqcriteria.html. 
[16] S. Wei, Y. Wang, J. C. W. Lam et al., "Historical trends of organic pollutants in sediment cores from Hong Kong," Marine Pollution Bulletin, vol. 57, no. 6-12, pp. 758-766, 2008.

[17] S. A. Bhat, G. Meraj, S. Yaseen, and A. K. Pandit, "Statistical assessment of water quality parameters for pollution source identification in Sukhnag stream, an inflow stream of Lake Wular (Ramsar site), Kashmir Himalaya," Journal of Ecosystems, vol. 2014, Article ID 898054, 18 pages, 2014.

[18] K. N. Don-Pedro, E. O. Oyewo, and A. A. Otitoloju, "Trend of heavy metal concentration in Lagos Lagoon ecosystem, Nigeria, West Africa," Journal of Applied Ecology, vol. 5, pp. 103-114, 2004.

[19] L. A. Pillsbury and R. H. Byrne, "Spatial and temporal chemical variability in the Hillsborough River system," Marine Chemistry, vol. 104, no. 1-2, pp. 4-16, 2007.

[20] P. R. Kannel, S. Lee, and Y. Lee, "Assessment of spatial-temporal patterns of surface and ground water qualities and factors influencing management strategy of groundwater system in an urban river corridor of Nepal," Journal of Environmental Management, vol. 86, no. 4, pp. 595-604, 2008.

[21] R. O. Strobl and P. D. Robillard, "Network design for water quality monitoring of surface freshwaters: a review," Journal of Environmental Management, vol. 87, no. 4, pp. 639-648, 2008.

[22] P. K. S. Shin and K. Y. S. Fong, "Multiple discriminant analysis of marine sediment data," Marine Pollution Bulletin, vol. 39, no. 1-12, pp. 285-294, 1999.

[23] S. Shrestha and F. Kazama, "Assessment of surface water quality using multivariate statistical techniques: a case study of the Fuji river basin, Japan," Environmental Modelling and Software, vol. 22, no. 4, pp. 464-475, 2007.

[24] D. Chapman, Water Quality Assessment, UNESCO, WHO and UNEP/Chapman and Hall, London, UK, 1992.

[25] M. Vega, R. Pardo, E. Barrado, and L. Debán, "Assessment of seasonal and polluting effects on the quality of river water by exploratory data analysis," Water Research, vol. 32, no. 12, pp. 3581-3592, 1998.

[26] S. K. Pradhan, D. Patnaik, and S. P. Rout, "Water quality index for the ground water around a phosphatic fertilizer plant," Indian Journal of Environmental Protection, vol. 21, no. 4, pp. 355-358, 2001.

[27] D. K. Sinha, S. Saxena, and R. Saxena, "Water quality index for Ram Ganga river water at Moradabad," Pollution Research, vol. 23, no. 3, pp. 527-531, 2004.

[28] M. Wu, Y. Wang, C. Sun et al., "Identification of coastal water quality by statistical analysis methods in Daya Bay, South China Sea," Marine Pollution Bulletin, vol. 60, no. 6, pp. 852-860, 2010.

[29] R. Reghunath, T. R. S. Murthy, and B. R. Raghavan, “The utility of multivariate statistical techniques in hydrogeochemical studies: An example from Karnataka, India," Water Research, vol. 36, no. 10, pp. 2437-2442, 2002.

[30] S. A. Bhat, G. Meraj, S. Yaseen, A. R. Bhat, and A. K. Pandit, "Assessing the impact of anthropogenic activities on spatiotemporal variation of water quality in Anchar lake, KashmirHimalayas," International Journal of Environmental Sciences, vol. 3, no. 5, pp. 1625-1640, 2013.

[31] K. Kannan, Fundamentals of Environmental Pollution, S. Chand and Company Limited, New Delhi, India, 1991.

[32] A. P. Singh and S. K. Ghosh, "Water quality index for river Yamuna,” Pollution Research, vol. 18, no. 4, pp. 435-439, 1999.

[33] W. W. Miller, H. M. Joung, C. N. Mahannah, and J. R. Garrett, "Identification of water quality differences in Nevada through index application," Journal of Environmental Quality, vol. 15, no. 3, pp. 265-272, 1986.

[34] A. A. Bordalo, R. Teixeira, and W. J. Wiebe, "A water quality index applied to an international shared river basin: the case of the Douro River," Environmental Management, vol. 38, no. 6, pp. 910-920, 2006.

[35] E. Sánchez, M. F. Colmenarejo, J. Vicente et al., "Use of the water quality index and dissolved oxygen deficit as simple indicators of watersheds pollution," Ecological Indicators, vol. 7, no. 2, pp. 315-328, 2007.

[36] K. Rumysa, A. A. Sharique, Z. Tariq, M. Farooq, A. Bilal, and K. Pinky, "Physico chemical status of Wular Lake in Kashmir," Journal of Chemistry, Biology and Physics Science, vol. 31, pp. 631-636, 2012.

[37] J. A. Sheikh, G. Jeelani, R. S. Gavali, and R. A. Shah, "Weathering and anthropogenic influences on the water and sediment chemistry of Wular Lake, Kashmir Himalaya," Environmental Earth Sciences, vol. 71, no. 6, pp. 2837-2846, 2014.

[38] M. R. D. Kundangar, S. G. Sarwar, and J. Husssain, "Zooplankton population and nutrient dynamics of wetlands of Wular lake, Kashmir, India," in Environment and Biodiversity in the Context of South Asia, P. K. Jha, G. P. S. Ghimire, S. B. Karmacharya, S. A. Baral, and P. Lacoul, Eds., pp. 128-134, Ecological Society (ECOS), Kathmandu, Nepal, 1996.

[39] J. A. Shah and A. K. Pandit, "Physico-chemical characteristics of water in Wular Lake' A Ramsar Site in Kashmir Himalaya," International Journal of Geology, Earth and Environmental Sciences, vol. 2, no. 2, pp. 257-265, 2012.

[40] S. A. Romshoo, N. Ali, and I. Rashid, "Geoinformatics for characterizing and understanding the spatio-temporal dynamics (1969 to 2008) of Hokersar Wetland in Kashmir Himalayas," International Journal of Physical Sciences, vol. 6, no. 5, pp. 10261038, 2011.

[41] S. A. Romshoo and I. Rashid, "Assessing the impacts of changing land cover and climate on Hokersar wetland in Indian Himalayas," Arabian Journal of Geosciences, vol. 7, no. 1, pp. 143160, 2014.

[42] E. O. Odada, D. O. Olago, K. Kulindwa, M. Ntiba, and S. Wandiga, "Mitigation of environmental problems in Lake Victoria, East Africa: causal chain and policy options analyses," Ambio, vol. 33, no. 1-2, pp. 13-23, 2004.

[43] R. Li, M. Dong, Y. Zhao, L. Zhang, Q. Cui, and W. He, "Assessment of water quality and identification of pollution sources of plateau lakes in Yunnan (China)," Journal of Environmental Quality, vol. 36, no. 1, pp. 291-297, 2007.

[44] G. Karakoç, F. Ünlü Erkoç, and H. Katircioǧlu, "Water quality and impacts of pollution sources for Eymir and Mogan Lakes (Turkey)," Environment International, vol. 29, no. 1, pp. 21-27, 2003.

[45] V. Kaul, "Water characteristics of some fresh water bodies of Kashmir," Current Trends in Life Sciences, vol. 9, pp. 221-246, 1979.

[46] A. K. Pandit and A. R. Yousuf, "Trophic status of Kashmir Himalayan lakes as depicted by water chemistry," Journal of Research and Development, vol. 2, pp. 1-12, 2002.

[47] M. A. Khan, "Chemical environment and nutrient fluxes in a flood plain wetland ecosystem, Kashmir Himalayas, India," Indian Forester, vol. 134, no. 4, pp. 505-514, 2008.

[48] F. A. Khan and A. A. Ansari, "Eutrophication: an ecological vision," Botanical Review, vol. 71, no. 4, pp. 449-482, 2005. 
[49] F. J. H. Mackereth, Some Methods for Water Analysis for Limnologists, vol. 21, Freshwater Biological Association, Science Publication, London, UK, 1963.

[50] H. L. Golterman and R. S. Clymo, "Methods for physical and chemical analysis of freshwaters," in IBP Hand Book No. 8, Blackwell Scientific Publications, Oxford, UK, 1969.

[51] American Public Health Association (A.P.H.A.), Standard Methods for Examination of Water and Waste Water, American Public Health Association, Washington, DC, USA, 20th edition, 1998.

[52] R. A. Johnson and D. W. Wichern, Applied Multivariate Statistical Analysis, Prentice Hall, Englewood Cliffs, NJ, USA, 3rd edition, 1992.

[53] A. C. Rencher, Method of Multivariate Analysis, John Wiley \& Sons, 2nd edition, 2002

[54] S. F. Pesce and D. A. Wunderlin, "Use of water quality indices to verify the impact of Cordoba City (Argentina) on Suquia River," Water Research, vol. 34, no. 11, pp. 2915-2926, 2000.

[55] R. K. Trivedy and P. K. Goel, Chemcial and Biological Methods for Water Pollution Studies, Environmental Publications, Karad, India, 1984.

[56] R. D. Harkins, "An objective water quality index," Journal of the Water Pollution Control Federation, vol. 46, no. 3, 1974.

[57] B. N. Lohani, "Water quality indices," in Water Pollution and Management Reviews, C. K. Varshney, Ed., pp. 53-69, South Asian Publications, New Delhi, India, 1981.

[58] T. N. Tiwari, S. C. Das, and P. K. Bose, "Water quality index for the river Jhelum in Kashmir and its seasonal variation," Pollution Research, vol. 5, no. 1, pp. 1-5, 1986.

[59] Indian Council of Medical Research, Manual of Standards of Quality of Drinking Water Supplied, Special Report Series no. 44, Indian Council of Medical Research, New Delhi, India, 2nd edition, 1975.

[60] United States Public Health Service, Public Health Service Drinking Water Standards, Publication No. 956, U. S. Department of Health, Education and Welfare Public Health Services, Washington, DC, USA, 1962.

[61] World Health Organization, Guidelines to Drinking Water Quality, vol. 1, World Health Organization, Geneva, Switzerland, 3rd edition, 2008.

[62] ISI, Indian Standard Specification for Drinking Water, 1983.

[63] S. Bamforth, "Ecological studies on the planktonic protozoa of a small artificial pond," Limnology of Oceanography, vol. 3, pp. 398-412, 1958.

[64] M. P. Sinha, R. Kumar, R. Srivastava, S. K. Mishra, and A. K. Choudhuri, "Ecotaxonomy and biomonitoring of lake for conservation and management, Biotic Profile," in Ecology and Conservation of Lakes, Reservoirs and Rivers, A. Kumar, Ed., vol. 2, pp. 248-289, ABD Publication, Jaipur, India, 2002.

[65] V. R. Solanki, M. M. Hussain, and S. S. Raja, "Water quality assessment of Lake Pandu Bodhan, Andhra Pradesh State, India," Environmental Monitoring and Assessment, vol. 163, no. 1-4, pp. 411-419, 2010.

[66] R. K. Garg, R. J. Rao, D. Uchchariya, G. Shukla, and D. N. Saksena, "Seasonal variations in water quality and major threats to Ramsagar reservoir, India," African Journal of Environmental Science and Technology, vol. 4, no. 2, pp. 61-76, 2010.

[67] Q. Lu, Z. L. He, D. A. Graetz, P. J. Stoffella, and X. Yang, "Phytoremediation to remove nutrients and improve eutrophic stormwaters using water lettuce (Pistia stratiotes L.)," Environmental Science and Pollution Research, vol. 17, no. 1, pp. 84-96, 2010.
[68] L. M. Bini, S. M. Thomaz, and P. Carvalho, "Limnological effects of Egeria najas Planchon (Hydrocharitaceae) in the arms of Itaipu Reservoir (Brazil, Paraguay)," Limnology, vol. 11, no. 1, pp. 39-47, 2010.

[69] D. D. Ratnayaka, M. J. Brandt, and K. M. Johnson, Water Supply, Butterworth-Heinemann, Boston, Mass, USA, 6th edition, 2009.

[70] M. E. Kotti, A. G. Vlessidis, N. C. Thanasoulias, and N. P. Evmiridis, "Assessment of river water quality in Northwestern Greece," Water Resources Management, vol. 19, no. 1, pp. 77-94, 2005.

[71] W. Yan, C. Yin, and S. Zhang, "Nutrient budgets and biogeochemistry in an experimental agricultural watershed in Southeastern China," Biogeochemistry, vol. 45, no. 1, pp. 1-19, 1999.

[72] Y. B. Si, S. Q. Wang, and H. M. Chen, "Water eutrophyication and losses of nitrogen and phosphrus in farmland," Soils, vol. 32, pp. 188-193, 2000 (Chinese).

[73] A. Vyas, D. D. Mishra, A. Bajapai, S. Dixit, and N. Verma, "Environment impact of idol immersion activity lakes of Bhopal, India," Asian Journal of Experimental Science, vol. 20, no. 2, pp. 289-296, 2006.

[74] P. Ekholm and K. Krogerus, "Bioavailability of phosphorus in purified municipal wastewaters," Water Research, vol. 32, no. 2, pp. 343-351, 1998.

[75] S. Mc Eldowney, D. J. Hardman, and S. Waite, Pollution: Ecology and Biotreatment, Longman, Essex, UK, 1993.

[76] M. A. Khan, M. A. Shah, S. S. Mir, and S. Bashir, "The environmental status of a Kashmir Himalayan wetland game reserve: Aquatic plant communities and eco-restoration measures," Lakes and Reservoirs: Research and Management, vol. 9, no. 2, pp. 125-132, 2004.

[77] S. A. Bhat, S. A. Rather, and A. K. Pandit, "Impact of effluent from Sheri-Kashmir Institute of Medical Sciences (SKIMS), Soura on Anchar Lake," Journal of Research and Development, vol. 1, pp. 30-37, 2001.

[78] Z. H. Zhu, "Phosphorates and silicate," in Researches on Ecosystem of Daya Bay, J. P. Pan, Ed., pp. 25-29, China Meteorological Press, Beijing, China, 1999.

[79] A. Astel, M. Biziuk, A. Przyjazny, and J. Namieśnik, "Chemometrics in monitoring spatial and temporal variations in drinking water quality," Water Research, vol. 40, no. 8, pp. 1706-1716, 2006.

[80] F. Zhou, Y. Liu, and H. Guo, "Application of multivariate statistical methods to water quality assessment of the watercourses in Northwestern New Territories, Hong Kong," Environmental Monitoring and Assessment, vol. 132, no. 1-3, pp. 1-13, 2007.

[81] N. M. Mattikalli and K. S. Richards, "Estimation of surface water quality changes in response to land use change: Application of the export coefficient model using remote sensing and geographical information system," Journal of Environmental Management, vol. 48, no. 3, pp. 263-282, 1996.

[82] H. Juahir, S. M. Zain, M. K. Yusoff et al., "Spatial water quality assessment of Langat River Basin (Malaysia) using environmetric techniques," Environmental Monitoring and Assessment, vol. 173, no. 1-4, pp. 625-641, 2011.

[83] P. Basnyat, L. D. Teeter, B. G. Lockaby, and K. M. Flynn, “The use of remote sensing and GIS in watershed level analyses of non-point source pollution problems," Forest Ecology and Management, vol. 128, no. 1-2, pp. 65-73, 2000. 
[84] D. G. Uzarski, T. M. Burton, M. J. Cooper, J. W. Ingram, and S. T. A. Timmermans, "Fish habitat use within and across wetland classes in coastal wetlands of the five Great Lakes, Development of a fish-based index of biotic integrity," Journal of Great Lakes Research, vol. 31, no. 1, pp. 171-187, 2005.

[85] M. A. Khan and M. A. Shah, "Hydrology and sediment loading of Hokersar wetland sanctuary in the Kashmir Himalaya, India," The Indian Forester, vol. 130, pp. 899-910, 2004.

[86] C. A. Biney, "A review of some characteristics of freshwater and coastal ecosystems in Ghana," Hydrobiologia, vol. 208, no. 1-2, pp. 45-53, 1990.

[87] R. F. Stallard and J. M. Edmond, "Geochemistry of the Amazon: 2. The influence of geology and weathering environment on the dissolved load.", Journal of Geophysical Research, vol. 88, no. 14, pp. 9671-9688, 1983.

[88] G. J. Chakrapani, "Water and sediment geochemistry of major Kumaun Himalayan lakes, India," Environmental Geology, vol. 43, no. 1-2, pp. 99-107, 2002.

[89] R. Venkatasubramani and T. Meenambal, "Study on subsurface water quality in Mettupalayam taluk of Coimbatore district, TamilNadu," Nature Environment and Pollution Technology, vol. 6, no. 2, pp. 307-310, 2007.

[90] A. Dagaonkar and D. N. Saksena, "Physico-chemical and biological characterization of a temple tank Kailasagar, Gwalior, Madhya Pradesh," Journal Hydrobiology, vol. 8, no. 1, pp. 11-19, 1992.

[91] H. L. Golterman and F. A. Kouwe, "Chemical budgets and nutrients pathways," in The functioning of ecosystems, E. D. Lecren and R. H. Lowe McConnel, Eds., vol. 22 of International Biological Program, pp. 85-140, London, UK, 1980.

[92] S. A. Bhat and A. K. Pandit, "Phytoplankton dynamics in Anchar Lake, Kashmir," Journal of Research and Development, vol. 3, pp. 71-96, 2003.

[93] G. Campbell and S. Wildberger, The Monitor's Handbook, a Reference Guide for Natural Water, 2005. 

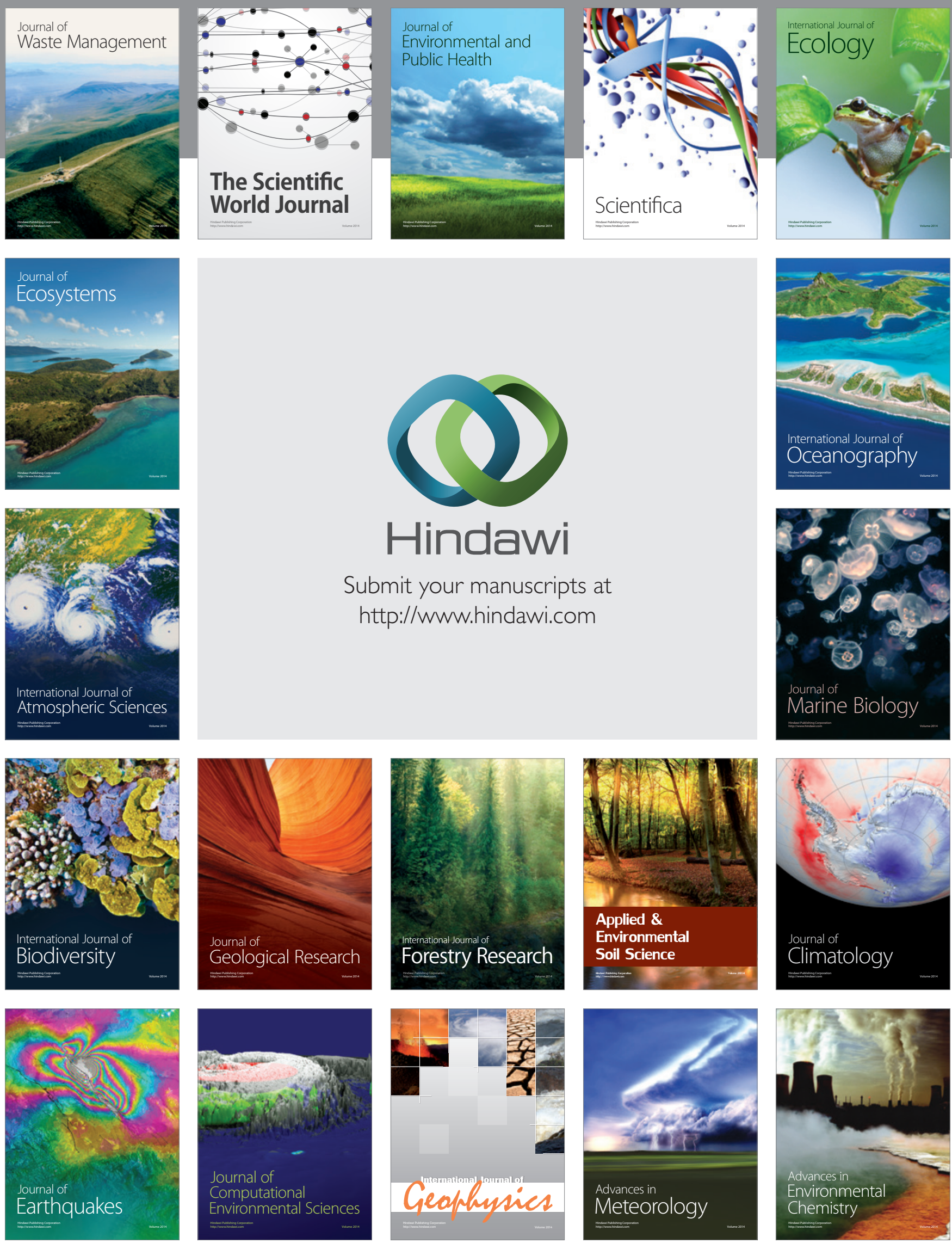